\title{
Adaptation of AMPK-mTOR-signal pathways and lipid metabolism in response to low- and high- rapeseed meal diet in Chinese perch (Siniperca chuatsi)
}

Jiao Li

Huazhong Agriculture University

Xu-Fang Liang ( $\nabla$ xufang_liang@hotmail.com )

Freshwater Institute https://orcid.org/0000-0002-6010-3066

Muhammad Shoaib Alam

Huazhong Agriculture University

Haocan Luo

Huazhong Agriculture University

Yanpeng Zhang

Huazhong Agriculture University

Binbin Peng

Huazhong Agriculture University

Qianqian Xiao

Huazhong Agriculture University

Zhilu Zhang

Huazhong Agriculture University

Liwei Liu

Huazhong Agriculture University

Shan He

Huazhong Agriculture University

\section{Research}

Keywords: plant protein, lipid accumulation, mTOR, AMPK, Siniperca chuatsi

Posted Date: March 13th, 2020

DOI: https://doi.org/10.21203/rs.3.rs-17136/v1

License: (a) This work is licensed under a Creative Commons Attribution 4.0 International License. Read Full License 
Page $2 / 27$ 


\section{Abstract}

Background: Chinese perch, a carnivorous fish, can accept artificial diet after domestication nowadays, and this farm way will gain high economic interest and sustainability. However, the high content and high quality requirement of dietary protein make it need the high cost in Chinese perch. Therefore, the aim of this study was to explore the effect of fish meal replacement by low- or high-rapeseed meal on growth performance, feeding, lipid and glucose metabolism. Methods: Three experimental diets were formulated with $0,10 \%$ and $30 \%$ rapeseed meal, named as control, RSL and $\mathrm{RSH}$, groups respectively. After the 8-week of feeding trial, growth performance, lipid metabolism and AMPK-mTOR-signal pathways were measured.

Results: Chinese perch fed with RSH and RSL diets showed significantly decreased WG, SGR, BFR, VSI, $\mathrm{MSI}$ and the whole-body crude lipid compared to those fed with the control diet $(P<0.05)$. Fish in RSL group decreased feed intake, serum LDL-C, hepatic mRNA expression of LPL, PEPCK and phosphorylated Grb10 $(P<0.05)$. In visceral adipose tissue, mRNA expression of FAS, SREBP1, ACC1, HL, CPT1 and PEPCK were all significantly down-regulated $(P<0.05)$. Fish in RSH group showed phosphorylated AMPK, hepatic mRNA expression of SREBP1, ACC1, FAS, PPARa and CPT1 were down-regulated, while HSL, G6PD and PC were up-regulated $(P<0.05)$. In visceral adipose tissue, mRNA expressions of SREBP1, LPL, CPT1 and PEPCK were down-regulated, while mRNA expression of HSL was up-regulated $(P<0.05)$.

Conclusions: Chinese perch fed with RSL and RSH diets showed decreased fat deposition in viscera. Fish fed with low level of rapeseed meal diet ate less diet, which caused inhibited lipid metabolism in the liver and visceral adipose tissues.Fish fed with high level of rapeseed meal diet inhibited hepatic FA synthesis, activated lipolysis, hence reducing Acetyl-CoA pool. In turn, $\beta$-oxidation were inhibited, glycolysis was activated, thus lipid accumulation was decreased. In visceral adipose tissue, lipid uptake was inhibited, caused inhibited FA synthesis, $\beta$-oxidation, glycerol synthesis, and improved lipolysis.

\section{Background}

Rapeseed is a crucial oilseed crop in the world, and its oil is one of the main edible oils source [1]. Rapeseed meal is the main co-products of the seed pressing and de-oiling processes [2], and it is an essential plant-protein source in mammals and fish [3]. Using the rapeseed meal replaced the fish meal partial or total for diets has been successfully attempted in some teleost fishes, such as rainbow trout (Oncorhynchus mykiss) [3], European seabass (Dicentrarchus labrax) [4],gilthead sea bream (Sparus aurata) [5]. In comparison with fish meal, the majority of plant-protein, such as rapeseed meal, is short of essential amino acids (EAA) and minerals besides it contains anti-nutritional factors (ANFs) and complex carbohydrates [5]. As an important kind of plant protein, the use of rapeseed is limited. However, despite these shortcomings, plant-protein has made great progress in its substitution in aquaculture. Nevertheless, recent studies have revealed that plant-protein affected lipid metabolism in the livers of salmonids [6-9]. 
The metabolism in mammals is regulated by nutrients and energy generally. AMPK is a serine/threonine protein kinase that regulates energy homeostasis, and is a chief kinase regulating mTOR signaling [10]. The mTOR protein kinase established a eukaryotic signaling network that coordinates the cell growth, nutrient metabolism and environmental conditions, Grb10 is key effector downstream of mTOR pathway [11]. As an essential regulator of lipid metabolism and energy homeostasis, Grb10 is relevant to lipolysis and thermogenesis [12].Moreover, activation of AMPK inhibited SREBP, which is a vital lipogenic transcription factor associated with biosynthesis of fatty acids. Activation of AMPK regulates PPARa positively, furthermore, activated fatty acid oxidation [13]. Activation of AMPK could also inhibit ACC activity directly, thereby reducing inhibition of CPT1, leading to an increase in fatty acid oxidation [14].

Chinese perch (Siniperca chuatsi) has great value in freshwater aquaculture of China for rapid growth and delicious flesh $[15,16]$. Chinese perch merely eat living bait from the initial feeding stage in wild [15]. However, after acceptance of artificial diet, Chinese perch gained high research and economic interest from aquaculture sector. As a carnivorous fish, Chinese perch has a high dietary protein requirement as other carnivorous fish, and the artificial diet of Chinese perch comprises a large portion of fish meal, which caused high dietary and aquaculture cost. As plant protein including rapeseed meal considered a good alternative cost-effective protein source, however the effect of plant protein on growth performance, lipid and glucose metabolism is still little explored, especially in carnivorous fishes. Therefore, the aim of the study was to explore the effect of fish meal replacement with low- and high-rapeseed meal diet on the adaptation of AMPK-mTOR-signal pathways and the lipid metabolism in Chinese perch (Siniperca chuatsi)..

\section{Methods}

\subsection{Experimental Diet}

Diet composition of the three experimental diets are shown in Table 6. The replacement levels of rapeseed meal were 0,10 and $30 \%$, respectively (named as Control, RSL and RSH). The ingredients were purchased from Coland (Wuhan, China). The soft granule diets were pelleted to cylinders form of $1 \mathrm{~cm}$ in diameter and $1 \mathrm{~cm}$ in length with the feed machine. Subsequently, the pellets were stored in a freezer at $20^{\circ} \mathrm{C}$ until used.

\subsection{Fish and Feeding Trial}

Chinese perch were brought from the Innovation Base for Chinese Perch Breeding (Wuhan, China). Before feeding trial, 250 fish were temporarily kept in 4 tanks (1000L) to weaned on artificial diet for 14 days. At the beginning of the experiment, fish were measured for initial weight and length after 24-hour starvation. Fish were randomly separated to three groups, and then every group has three randomly assigned tanks. Furthermore, every tank contained 15 fish ( $48.78 \pm 4.37 \mathrm{~g})$. Fish were fed to apparent satiation twice a day at 08:00 and 17:00 in the course of the 8-weeks feeding trial. Uneaten feed was collected and dried after feeding for feed intake and FCR measurement. The filtered flow-through tap water was system was 
used at a water flow-rate of $3 \mathrm{~L}$ min-1. The dissolved oxygen (DO) value was $8.25-8.76 \mathrm{mg} L-1$, the temperature ranged from 20 to $22{ }^{\circ} \mathrm{C}$, the ammonia content was $0.10 \pm 0.02 \mathrm{mg} \mathrm{L}-1$ and pH ranged from 7.20 to 7.60 in the course of the experimental period.

\subsection{Sampling, Body composition and Serum Biochemistry Parameters}

After 24-hour starvation, fish were anaesthetized with MS-222 (50 mg L-1 water). Afterwards, final body weight, fish length, visceral mass weight, liver weight and gut weight were measured. After that nine fish were randomly chosen from each tank for western-bloting and RT-PCR analysis. The livers, visceral adipose and brains of Chinese perch were dissected out, frozen in liquid nitrogen and stored at $-80{ }^{\circ} \mathrm{C}$ for subsequent analysis. The blood was collected from caudle vein and placed at room temperature for $2 \mathrm{~h}$. Then serum was separated after centrifuged at $3,500 \mathrm{~g}$ for $10 \mathrm{~min}$, and stored it at $-80{ }^{\circ} \mathrm{C}$ until used. Three fish were chosen randomly from each tank to analyses whole body composition.

Proximate compositions (Crude protein, crude lipid, moisture and crude ash) of experimental diets, whole body, fish liver and fish muscle were measured according to AOAC, 1995 method [17]. Samples were dried at $105^{\circ} \mathrm{C}$ for $6 \mathrm{~h}$ using the ovens, then the moisture was measured. Crude protein $(\mathrm{N} \times 6.25)$ was evaluated referring the Kjeldahl method. Samples were measured with the Kjeltec system (Kjeltec 2300 Analyzer, Foss Tecator, Sweden) after acid digestion. Crude lipid was examined by the ether-extraction method using Soxtec System HT (Soxtec System HT6, Tecator, Sweden). Crude ash was evaluated using a muffle furnace at $550{ }^{\circ} \mathrm{C}$ for $12 \mathrm{~h}$. Cross energy of three experimental diets was examined by bomb calorimetry using a Parr 6200 calorimeter equipped with a Parr 1108 Oxygen Bomb and a Parr 6510 water handling system (Parr Instrument Company, Moline, IL, USA).

Serum biochemistry parameters (GLU, Cholesterol, TG, HDL-C and LDL-C) were evaluated using the automatic biochemical analyzer [Abbott Aeroset Analy zer (Abbott Laboratories, Abbott Park, IL, USA)] in the Zhongnan Hospital of Wuhan University (Wuhan, Hubei, China).

\subsection{Real-time PCR assay}

Total RNA was extracted by RNAiso Plus reagent (Takara, Japan). The purity and quantity of RNA was examined by using the BioTek Synergy ${ }^{\mathrm{TM}} 2$ Multi-detection Microplate Reader (BioTek Instruments, Winooski, VT) and by $1.5 \%$ agarose gel electrophoresis. Afterward we reverse transcribed $1 \mu \mathrm{g}$ of RNA into cDNA using SuperScript ${ }^{\mathrm{TM}}$ II RT reverse transcriptase (Takara, Japan).

Gene-specific primers for Real-time PCR are shown in Table 7. The primers sequences are based on the published transcriptome sequences of Chinese perch [18]. We evaluated the stability of RPL 13A, $\beta$-actin, HMBS, B2M, SDHA and YWHA2 following the previous studies [19]. That RPL 13A gene was more stable and amplified as the internal control. Real-time PCR was evaluated using a quantitative thermal cycler (MyiQTM 2 Two-Color Real-Time PCR Detection System, BIO-RAD, USA). The reaction volume (20 $\mu \mathrm{L})$

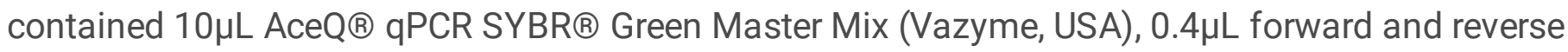


primers $(10 \mathrm{mM})$ respectively, $1 \mu \mathrm{L}$ cDNA and $8.2 \mu \mathrm{L}$ sterile double-distilled water. The PCR parameters were $95{ }^{\circ} \mathrm{C}$ for $1 \mathrm{~min}$ followed by 40 cycles at $95^{\circ} \mathrm{C}$ for $10 \mathrm{sec}$, Tm for $30 \mathrm{sec}$ and a melt curve step (from $95{ }^{\circ} \mathrm{C}$, gradually reducing $0.5^{\circ} \mathrm{C} \mathrm{s}-1$ to $57^{\circ} \mathrm{C}$, with acquisition data every $6 \mathrm{sec}$ ). The amplification efficiencies of reference gene and target genes ranged from 95.9 to $105.4 \%$. Expressions of mRNA were quantified relative to the expression of $R P L 13 A$ according to the optimized comparative $C t{ }^{(2-\triangle \triangle C t)}$ value method [20]. Amplification was performed in triplicate for each cDNA sample.

\subsection{Western-blotting assay}

The frozen samples were lysed in radioimmunoprecipitation (RIPA) assay buffer containing 1\% protease inhibitor (PMSF) (Nanjing KeyGen Biotech, China) on ice. Protein concentrations were examined with the BCA protein assay kit (Beyotime, China). Chose equivalent amounts of protein $(20 \mu \mathrm{g})$ to separate by SDS-PAGE gel, and then transferred to PVDF membranes (Millipore, USA). After blocking 4 hours with $5 \%$ non-fat milk, membranes were incubated overnight at $4^{\circ} \mathrm{C}$ in primary antibodies diluted in TBST containing 5\% BSA. The primary antibodies include: p-AMPK (1:1000; Cell Signaling, \#2537), p-Grb10 (1:1000; Cell Signaling, \#11817), $\beta$-tublin antibody (1:100000, Bioss, bs-20694R). Subsequently, fluorescent labeling second antibodies (IRDye ${ }^{\circledR} 680$ or $800 \mathrm{cw}$ goat anti-rabbit, or goat anti-mouse 1:8000 dilution, Licor, Lincoln, NE, USA) were incubated for $1 \mathrm{~h}$ at room temperature. The relative density of bands was detected by the LiCor Odyssey scanner (LI-COR Bioscience, USA). The densitometric values were normalized by using the merits of $\beta$-actin (or $\beta$-tublin).

\subsection{Statistical analyses}

The data were calculated for WG, SGR, FCR, CF, BFR, VSI, HSI, MSI and Feed Intake using the following formula:

$W G=100 \times($ final weight-initial weight $) /$ initial weight;

$S G R=100 \times($ In final weight - In initial weight $) /$ days;

$\mathrm{FCR}=100 \times$ total feed intake $/$ weight gain;

$\mathrm{CF}=100 \times$ final weight $/$ (final length)3;

$\mathrm{BFR}=$ visceral fat weight $/$ body weight $* 100$

VSI = $100 \times$ (viscera weight $/$ whole body weight);

$\mathrm{HSI}=100 \times$ (liver weight/whole body weight);

MSI = $100 \times$ (gut weight $/$ whole body weight);

Feed Intake $=$ total feed intake $/$ (initial fish number $\times \mathrm{SR} \times$ day number) . 
All statistical analyses were carried out using the SPSS 19.0. Data are shown as means \pm S. E.M of triplicates. Before one-way ANOVA, all data were subjected to One Sample T-test and normality and homogeneity test. Differences were considered significant at $P<0.05$.

\section{Results}

\subsection{Growth performance}

After the 8-week of feeding trial, the growth performance of Chinese perch fed with high and low levels of rapeseed meal diets are shown in Table 1, and Table 2 respectively. Fish fed with RSH and RSL diets showed significantly inhibited growth performance including the weight gain and SGR, with compared to control diet $(P<0.05)$ (Table. 1). Fish fed with RSH diet showed significantly ascended in FCR, as compared with the control diet $(\mathrm{P}<0.05)$. Moreover, $\mathrm{CF}$ in RSH group was significantly reduced as compared to control group diet $(P<0.05)$ (Table 2). The BFR and MSI in RSH and RSL groups were significantly reduced as compared to control group $(P<0.05)$, while there was no significant difference observed in $\mathrm{HSI}$ ratio among all groups $(\mathrm{P}>0.05)$ (Table 2$)$.

\subsection{Feed intake and appetite genes expression}

The feed intake in RSL group was significantly inhibited in comparison to control group $(P<0.05)$ (Figure 1). The genes expressions involved in appetite regulation of Chinese perch are shown in Figure 2. The gene expression of $N P Y$ was significantly decreased in RSH group, while the gene expression of $A g R P$ was significantly increased in RSL group, whereas gene expression of leptin $A$ was significantly increased in $\mathrm{RSH}$ group $(\mathrm{P}<0.05)$.

\subsection{Whole body, tissue composition}

The composition of whole body in Chinese perch fed with high and low levels of rapeseed meal diets was shown in Table 3. The crude lipid and moisture in whole body was significantly decreased in RSH and RSL groups as compared with control group $(P<0.05)$, the crude ash in whole body were significantly increased in RSL group as compared with control group $(P<0.05)$. The tissue composition of Chinese perch fed with high and low levels of rapeseed meal diets was presented in Table 4. The moisture in liver was significantly increased in RSH and RSL groups by comparison to control group $(P<0.05)$. No significant difference was found in crude protein and crude lipid of liver. Moreover, no significant difference was found in muscle composition including moisture, crude protein and crude lipid $(P>0.05)$.

\subsection{Serum biochemistry parameters}

The serum biochemistry parameters of Chinese perch fed with high and low levels of rapeseed meal diets are shown in Table 5. Serum LDL-C were significantly decreased in RSH and RSL groups as compared to 
control group $(P<0.05)$. The serum glucose and cholesterol were significantly decreased in RSH group as compared to control group $(P<0.05)$. No significant difference was observed in TG and HDL-C $(P>0.05)$.

\subsection{Gene expressions of glucose and lipid metabolism in liver of Chinese perch}

Expressions of genes involved in glucose and lipid metabolism of Chinese perch liver fed with high and low levels of rapeseed meal diets are shown in Figure 3. The metabolic regulatory factors involved in lipid metabolism, such as SREBP1 and PPARa, were all decreased in RSH group significantly $(\mathrm{P}<0.05)$ (Figure $3 A)$. Moreover, genes involved in fatty acid synthesis, such as $F A S$ and $A C C 1$, were all decreased significantly in RSH group, while expression of $A C C 1$ in RSL group was increased significantly $(P<0.05)$ (Figure 3B). Genes involved in FA transport, such as $H L$ and $L P L$, were checked. The expression of $L P L$ in RSL group was decreased significantly $(P<0.05)$, while no significant difference was found in the expression of $H L(P>0.05)$ (Figure $3 C$ ). the expression of $H S L$, an important gene involved in lipolysis, was increased in RSH group ( $\mathrm{P}<0.05)$ (Figure 3D). Expression of $C P T 1$, an important gene involved in fatty acid $\beta$-oxidation, was decreased in RSH group $(P<0.05)$ (Figure $3 \mathrm{E})$. the expression of PEPCK, involved in glycerol synthesis, was increased significantly in RSH group as compared to RSL group $(\mathrm{P}<$ 0.05 ) (Figure 3F). In addition, genes involved in glycolysis, such as G6PD and $P C$, were significantly increased in RSH group $(P<0.05)$ (Figure 3G).

\subsection{Gene expressions of lipid metabolism in visceral adipose tissue of Chinese perch}

The expressions of genes involved in glucose and lipid metabolism of Chinese perch visceral adipose tissue are shown in Figure 4. The expression of SREBP1 was significantly decreased in RSL and RSH groups $(P<0.05)$ (Figure $4 A)$, while the expression of $A C C 1$ was significantly decreased in RSL group $(P<$ 0.05) (Figure $4 \mathrm{~B}$ ). the expression of $\mathrm{HL}$ was significantly decreased in RSL group, while expression of LPL was significantly decreased in RSH group $(P<0.05)$ (Figure 4C). the gene expression of HSL was significantly increased in RSH group $(P<0.05)$ (Figure 4D). The expressions of CPT1 and PEPCK were significantly decreased in RSL and RSH groups $(P<0.05)$ (Figure $4 E, F)$.

\subsection{Protein activation levels Analysis of AMPK and mTOR pathway of Chinese perch}

Phosphorylation levels of AMPK, Grb10 in liver of Chinese perch fed with high and low levels of rapeseed meal diets are shown in Figure 5-6. In comparison with control group, the phosphorylation level of AMPK was improved significantly in RSH group $(P<0.05)$ (Figure 5), In addition, the phosphorylation level of Grb10 had significant difference between RSL and RSH groups $(P<0.05)$, while no significant difference was observed control group and RSH group $(P>0.05)$ (Figure 6). 


\section{Discussion}

As an important source of plant-protein, rapeseed meal was used to replace dietary fish meal in many teleost fishes successfully [3-5]. Nevertheless, due to poor palatability, high anti-nutrititional factors (ANFs) and amino acid imbalance of rapeseed meal, fish will contribute to poor appetite and slow growth [21]. In our study, Chinese perch fed with low or high levels of rapeseed meal both lead to impoverished weight gain and SGR. Similar results were found in juvenile cobia [21], rainbow trout [22], hybrid tilapia [23] and Japanese seabass [24]. This result suggests that the nutrient content of rapeseed meal could not satisfy the growth of Chinese perch compared to fish meal. However, FCR in RSH group was significantly higher than the other two groups in the present study, indicating that low level replacement of rapeseed meal diet caused no significant negative effect on FCR of Chinese perch, while high level replacement of rapeseed meal diet enhanced FCR significantly. It is suggested that excessive rapeseed meal in diet could affect the utilization of Chinese perch.

Some studies showed that less feed intake was one of the reasons for reduced growth performance in fish [22]. In our study, feed intake in RSL group was lower than other two groups. Studies have confirmed that plant-protein rich in ANFs, which makes diet less palatability [25]. This might be the reason why Chinese perch accepted less low-level rapeseed meal diet in the present study. The consequence also illustrated the reason why Chinese perch grew slowly in RSL group. The conclusion was consistent with Chinook salmon [26], rainbow trout [27] and cobia [21]. However, feed intake in RSH group was not affected by high level replacement of rapeseed meal diet, which might be for the reason that the feed utilization ability of Chinese perch in RSH group was poor and they had to take in the diets to meet their body needs. The conclusion was consistent with Japanese seabass [24]. Fish appetite is regulated by appetite-regulating hormones [28]. In the mammalian, NPY and AgRP located at appetite stimulating neurons jointly, while the POMC located at appetite suppressing neurons [29-31]. Leptin is recognized as peripheral appetite genes to suppress appetite [32]. Expression of $N P Y$ was significantly down-regulated, while expression of Leptin A was significantly up-regulated in RSH group, suggesting that high level replacement of rapeseed meal diet inhibited appetite of Chinese perch by down-regulating mRNA level of $N P Y$ and Leptin A. Grass carp fed with plant-protein diets showed low expression of NPY after 24 hours of starvation [33], the result was consistent with our study, this suggests that plant-protein affected the expression of appetite-related genes. In combination with feed intake in RSH group, although fish accepted high level replacement of rapeseed meal diet a lot, but the appetite was inhibited. Expression of $A g R P$ was significantly up-regulated in RSL group, that shows that fish in RSL group was in the active state of appetite. Similar results were found in Japanese seabass [24]. In combination with feed intake in RSL group, Chinese perch had an active appetite due to the low feed intake. The expression of appetiterelated genes showed a compensatory response.

The CF of a fish is an indicator of nutrition and adaptation to the environment. It is also relevant to the meat content of fish. The low and high CF, means that the fish is thin or fat [34]. Fish fed with high level of rapeseed meal diet had a lower CF compared to other two groups. Similar results were found in gilthead sea bream fed with plant protein sources diets containing rapeseed meal [35], this shows that 
high level rapeseed meal affected fat deposition. However, the VSI, BFR and MSI in fish fed with low and high levels of rapeseed meal diets decreased as compared to control group, while no significant difference was found in HSI. Similar results were found in gilthead sea bream[35], and in Salminus brasiliensis [36]. The results further proved that the replacement of rapeseed meal could decrease fat deposition in viscera rather than the liver. The composition of whole body, liver and muscle tissue were measured to further prove this hypothesis. Crude lipid in whole body of fish fed with low and high levels of rapeseed meal diets decreased as compared to control group, while no significant difference was found in liver and muscle. Combined with the above results, the replacement of rapeseed meal with fish meal could decrease fat deposition in viscera rather than in liver.

In the present study, serum glucose and cholesterol were significantly decreased in RSH group, while no significant difference was observed in TG. The effect of plant protein on blood glucose in fish depends on fish species, the source and level of plant protein [37]. Japanese seabass fed with a full plant protein diet decreased blood glucose level [38]. However, there was no significant difference in blood glucose of Trachinotus carolinus fed with soybean meal diet was observed [37, 39]. Our study revealed that high level of rapeseed meal could decrease blood glucose, which suggests that glucose uptake into tissues and glucose phosphorylation levels might be improved. Numerous studies had found that plant protein diets can reduce serum cholesterol levels in rainbow trout [40], European seabass [41] and Psetta maxima [42]. Our results were consistent with the conclusion, that the effect of high level of rapeseed meal on lowering plasma cholesterol in fish might be related to the low cholesterol content in feed [43]. LDL-C carries cholesterol from the liver to tissues, while HDL-C carries cholesterol back from tissues back to the liver for metabolism. In our study, serum LDL-C was significantly decreased in RSH and RSL groups as compared to control group, while no significant difference was observed in HDL-C. This result suggests that the replacement of rapeseed meal reduced the transport of cholesterol from the liver to tissues.

Chinese perch fed with low and high level of rapeseed meal diet all decreased fat deposition in viscera. Grb10 could promote lipolysis and thermogenesis by negative regulation of the mTOR signaling pathway [12]. In our study, fish fed with low level replacement of rapeseed meal diet phosphorylated Grb10, indicated that diet with low level of rapeseed meal could activate Grb10, and inhibit mTOR pathway, that enhanced lipolysis and thermogenesis of Chinese perch. Similar results were found in grass carp [44] and juvenile white shrimp [45], the results are in line with other studies. Furthermore, lipid and glucose metabolism related genes were measured to demonstrate the specific mechanism of Chinese perch response to rapeseed meal. In liver tissue, mRNA expression of $A C C 1$, which is involved in FA synthesis, was up-regulated, while mRNA expression of $L P L$, which is involved in lipid uptake, was down-regulated in Chinese perch fed with low level of rapeseed meal diet. It is suggested that Chinese perch fed with low level of rapeseed meal diet promoted FA synthesis, and inhibited lipid uptake in liver tissue. Similar results were found in Japanese seabass [38]. It is suggested that the reduction in fat accumulation caused by low level of rapeseed meal did not occur in the liver mainly. In visceral adipose tissue, mRNA expression of FA synthesis related genes (SREBP1, ACC1),, lipid uptake relative gene ( $H L)$," fatty acid $\beta$ oxidation relative gene (CPT1) and glycerol synthesis relative gene (PEPCK) were all down-regulated. It is suggested that the reduction in fat accumulation caused by the low level of rapeseed meal occurred in 
the visceral adipose mainly, all fat metabolic activity was suppressed. Combined with food intake results, the results show that fish in RSL group ate less food and lipid, which caused inhibited lipid metabolism in the liver and visceral adipose tissues.

AMPK has been considered as a sensitive energy sensor in cells [46]. In our study, high level of rapeseed meal diet significantly activated AMPK pathway in Chinese perch. This shows that the lack of energy intake of Chinese perch in RSH group activated the energy-sensing pathway. Similar results were observed in turbot [47]. In liver tissue, mRNA expression of FA synthesis relative genes (SREBP1, ACC1 and $F A S$ ) were down-regulated, mRNA expression of fatty acid $\beta$-oxidation relative genes (PPARa and CPT1) were all down-regulated, mRNA expression of lipolysis relative gene (HSL) was up-regulated, while mRNA expression of glycolysis related genes (G6PD and $P C$ ) were up-regulated. It is suggested that FA synthesis was inhibited, while lipolysis was promoted, these metabolic processes caused Acetyl-CoA pool reduced. The fatty acid $\beta$-oxidation were inhibited, and glycolysis was promoted, lipid accumulation was decreased when Chinese perch fed with high level replacement of rapeseed meal diet. At the same time in visceral adipose tissue, mRNA expressions of SREBP1, LPL, CPT1 and PEPCK were down-regulated, while mRNA expression of HSL was up-regulated. It is suggested that lipid uptake was inhibited, that caused FA synthesis, and fatty acid $\beta$-oxidation, glycerol synthesis were inhibited, which caused improved lipolysis.

\section{Conclusion}

Chinese perch fed with RSL and RSH diets showed decreased fat deposition in viscera. Fish fed with low level of rapeseed meal diet showed decreased in feed intake, serum LDL-C, hepatic mRNA expression of $L P L$ and PEPCK and phosphorylated Grb10. In visceral adipose tissue, mRNA expression of FA synthesis related genes (SREBP1, ACC1), lipid uptake relative gene (HL), $\beta$-oxidation relative gene (CPT1) and glycerol synthesis relative gene (PEPCK) were all down-regulated, this show that fish in RSL group ate less diet, which caused inhibited lipid metabolism in the liver and visceral adipose tissues.

Fish fed with high level of rapeseed meal diet showed phosphorylated AMPK, hepatic mRNA expression of FA synthesis relative genes (SREBP1, ACC1 and FAS) was down-regulated, while lipolysis relative gene (HSL) was up-regulated, and these metabolic processes reduced Acetyl-CoA pool. In turn, $\beta$-oxidation relative genes (PPARa and CPT1) were all down-regulated, while glycolysis relative genes (G6PD and PC) was up-regulated, thus lipid accumulation were decreased. In visceral adipose tissue, mRNA expression of SREBP1, LPL, CPT1 and PEPCK was down-regulated, while mRNA expression of HSL was up-regulated, which shows that lipid uptake were inhibited, caused inhibited FA synthesis, $\beta$-oxidation, glycerol synthesis, and improved lipolysis.

\section{List Of Abbreviations}

AMP-activated protein kinase, AMPK; Mammalian target of rapamycin, mTOR; Sterol regulatory element binding protein, SREBP; Peroxisome proliferator-activated receptor-a, PPARa; Acetyl-CoA carboxylase, ACC; Carnitine palmitoyltransferase I, CPT1; Weight gain, WG; Specific growth ratio, SGR; Feed conversion 
ratio, FCR; Condition factor, CF; Body Fat Ratio, BFR; Viscerosomatic index, VSl; Hepatosomatic index, HSl; Mesentery fat index, MFI; Glucose, GLU; Triglyceride, TG; High density lipoprotein, HDL; Low density lipoprotein, LDL; NPY, neuropeptide Y; Agouti-related peptide, AgRP; Pro-opiomelanocortin, POMC; Fatty acid synthase, FAS; Hepatic lipase, HL; Lipoprotein lipase, LPL; Hormone-sensitive lipase, HSL; Phosphoenol pyruvate carboxykinase, PEPCK; Glucose-6-phosphatase, G6PD; Pyruvate carboxylase, PC.

\section{Declarations}

\section{Ethics approval and consent to participate}

All experimental procedures followed the guidance for animal protocol and were approved by Huazhong Agricultural University (Wuhan, Hubei, China).

\section{Consent for publication}

Not applicable

\section{Availability of data and materials}

All data used to arrival at conclusions of this paper are present in this manuscript. The raw data is available from the authors on request.

\section{Competing interests}

The authors declare that they have no competing interests.

\section{Funding}

China Agriculture Research System (CARS-46); National Key R\&D Program of China (2018YFD0900400), the National Natural Science Foundation of China (31772822).

\section{Authors' contributions}

Xu-Fang Liang conceived and designed the experiments; Jiao Li, Muhammad Shoaib Alam, Haocan Luo, Yanpeng Zhang, Binbin Peng, Qianqian Xiao, Zhilu Zhang, Shan He, and Liwei Liu performed the experiments; Haocan Luo, Yanpeng Zhang and Binbin Peng, Muhammad Shoaib Alam, completed in feeding trial; Jiao Li, Muhammad Shoaib Alam, Qianqian Xiao, Zhilu Zhang and Shan He write and revised the manuscript. 


\section{Acknowledgments}

This work was financially supported by China Agriculture Research System (CARS-46); National Key R\&D Program of China (2018YFD0900400), the National Natural Science Foundation of China (31772822).

\section{Author details}

a College of Fisheries, Chinese Perch Research Center, Huazhong Agricultural University, Wuhan 430070, China;

b Innovation Base for Chinese Perch Breeding, Key Lab of Freshwater Animal Breeding, Ministry of Agriculture, Wuhan 430070, China.

\section{References}

1. Lomascolo A, Uzan-Boukhris E, Sigoillot J-C, Fine F. Rapeseed and sunflower meal: a review on biotechnology status and challenges. Applied microbiology and biotechnology. 2012;95(5):1105-14.

2. Laguna O, Odinot E, Bisotto A, Baréa B, Villeneuve P, Sigoillot J-C, et al. Release of phenolic acids from sunflower and rapeseed meals using different carboxylic esters hydrolases from Aspergillus niger. Industrial Crops and Products. 2019;139:111579.

3. Burel C, Boujard T, Escaffre AM, Kaushik SJ, Boeuf G, Mol KA, et al. Dietary low-glucosinolate rapeseed meal affects thyroid status and nutrient utilization in rainbow trout (Oncorhynchus mykiss). Brit J Nutr. 2000;83(6):653-64.

4. Kaushik SJ, Coves D, Dutto G, Blanc D. Almost total replacement of fish meal by plant protein sources in the diet of a marine teleost, the European seabass, Dicentrarchus labrax. Aquaculture. 2004;230(1-4):391-404.

5. Sitja-Bobadilla A, Pena-Llopis S, Gomez-Requeni P, Medale F, Kaushik S, Perez-Sanehez J. Effect of fish meal replacement by plant protein sources on non-specific defence mechanisms and oxidative stress in gilthead sea bream (Sparus aurata). Aquaculture. 2005;249(1-4):387-400.

6. Vilhelmsson OT, Martin SA, Medale F, Kaushik SJ, Houlihan DF. Dietary plant-protein substitution affects hepatic metabolism in rainbow trout (Oncorhynchus mykiss). Br J Nutr. 2004;92(1):71-80.

7. Panserat S, Kolditz C, Richard N, Plagnes-Juan E, Piumi F, Esquerre D, et al. Hepatic gene expression profiles in juvenile rainbow trout (Oncorhynchus mykiss) fed fishmeal or fish oil-free diets. $\mathrm{Br} \mathrm{J}$ Nutr. 2008;100(5):953-67.

8. Leaver MJ, Villeneuve LA, Obach A, Jensen L, Bron JE, Tocher DR, et al. Functional genomics reveals increases in cholesterol biosynthetic genes and highly unsaturated fatty acid biosynthesis after dietary substitution of fish oil with vegetable oils in Atlantic salmon (Salmo salar). BMC Genomics. 2008;9:299. 
9. Jordal AE, Torstensen BE, Tsoi S, Tocher DR, Lall SP, Douglas SE. Dietary rapeseed oil affects the expression of genes involved in hepatic lipid metabolism in Atlantic salmon (Salmo salar L.). J Nutr. 2005;135(10):2355-61.

10. Carretero J, Medina PP, Blanco R, Smit L, Tang M, Roncador G, et al. Dysfunctional AMPK activity, signalling through mTOR and survival in response to energetic stress in LKB1-deficient lung cancer. Oncogene. 2007;26(11):1616-25.

11. Saxton RA, Sabatini DM. mTOR Signaling in Growth, Metabolism, and Disease. Cell. 2017;169(2):361-71.

12. Liu B, Liu F. Feedback regulation of mTORC1 by Grb10 in metabolism and beyond. Cell Cycle. 2014;13(17):2643-4.

13. Lee WJ, Kim M, Park HS, Kim HS, Jeon MJ, Oh KS, et al. AMPK activation increases fatty acid oxidation in skeletal muscle by activating PPARalpha and PGC-1. Biochem Biophys Res Commun. 2006;340(1):291-5.

14. Murase T, Misawa K, Haramizu S, Minegishi Y, Hase T. Nootkatone, a characteristic constituent of grapefruit, stimulates energy metabolism and prevents diet-induced obesity by activating AMPK. Am J Physiol Endocrinol Metab. 2010;299(2):E266-75.

15. Liang XF, Liu JK, Huang BY. The role of sense organs in the feeding behaviour of Chinese perch. J Fish Biol. 1998;52(5):1058-67.

16. Liang XF, Oku H, Ogata HY, Liu J, HeX. Weaning Chinese perch Siniperca chuatsi (Basilewsky) onto artificial diets based upon its specific sensory modality in feeding. Aquac Res. 2001;32:76-82.

17. AOAC, Horwitz W. Official methods of analysis of the association of official analytical chemists. AOAC International, Arlington VA. 1995.

18. He S, Liang XF, Sun J, Li L, Yu Y, Huang W, et al. Insights into food preference in hybrid F1 of Siniperca chuatsi (female) $x$ Siniperca scherzeri (male) mandarin fish through transcriptome analysis. Bmc Genomics. 2013;14.

19. Vandesompele J, De Preter K, Pattyn F, Poppe B, Van Roy N, De Paepe A, et al. Accurate normalization of real-time quantitative RT-PCR data by geometric averaging of multiple internal control genes. Genome Biol. 2002;3(7).

20. Livak KJ, Schmittgen TD. Analysis of relative gene expression data using real-time quantitative PCR and the 2(T)(-Delta Delta C) method. Methods. 2001;25(4):402-8.

21. Luo YW, Ai QH, Mai KS, Zhang WB, Xu W, Zhang YJ. Effects of dietary rapeseed meal on growth performance, digestion and protein metabolism in relation to gene expression of juvenile cobia (Rachycentron canadum). Aquaculture. 2012;368:109-16.

22. Hilton JW, Slinger SJ. Digestibility and Utilization of Canola-Meal in Practical-Type Diets for Rainbow-Trout (Salmo-Gairdneri). Can J Fish Aquat Sci. 1986;43(6):1149-55.

23. Zhou QC, Yue YR. Effect of replacing soybean meal with canola meal on growth, feed utilization and haematological indices of juvenile hybrid tilapia, Oreochromis niloticus $x$ Oreochromis aureus. Aquac Res. 2010;41(7):982-90. 
24. Cheng ZY, Ai QH, Mai KS, Xu W, Ma HM, Li Y, et al. Effects of dietary canola meal on growth performance, digestion and metabolism of Japanese seabass, Lateolabrax japonicus. Aquaculture. 2010;305(1-4):102-8.

25. Webster CD, Tiu LG, Tidwell JH, Grizzle JM. Growth and body composition of channel catfish (Ictalurus punctatus) fed diets containing various percentages of canola meal. Aquaculture. 1997;150(1-2):103-12.

26. Satoh S, Higgs DA, Dosanjh BS, Hardy RW, Eales JG, Deacon G. Effect of extrusion processing on the nutritive value of canola meal for chinook salmon (Oncorhynchus tshawytscha) in seawater. Aquacult Nutr. 1998;4(2):115-22.

27. Shafaeipour A, Yavari V, Falahatkar B, Maremmazi JG, Gorjipour E. Effects of canola meal on physiological and biochemical parameters in rainbow trout (Oncorhynchus mykiss). Aquacult Nutr. 2008;14(2):110-9.

28. Aldegunde $M$, Mancebo $M$. Effects of neuropeptide $Y$ on food intake and brain biogenic amines in the rainbow trout (Oncorhynchus mykiss). Peptides. 2006;27(4):719-27.

29. Shanley LJ, Irving AJ, Harvey J. Leptin enhances NMDA receptor function and modulates hippocampal synaptic plasticity. J Neurosci. 2001;21(24):art. no.-RC186.

30. During MJ, Cao L, Zuzga DS, Francis JS, Fitzsimons HL, Jiao XY, et al. Glucagon-like peptide-1 receptor is involved in learning and neuroprotection. Nat Med. 2003;9(9):1173-9.

31. Diano S, Farr SA, Benoit SC, McNay EC, da Silva I, Horvath B, et al. Ghrelin controls hippocampal spine synapse density and memory performance. Nat Neurosci. 2006;9(3):381-8.

32. Yuan XC, Li AX, Liang XF, Huang W, Song Y, He S, et al. Leptin expression in mandarin fish Siniperca chuatsi (Basilewsky): Regulation by postprandial and short-term fasting treatment. Comp Biochem Phys A. 2016;194:8-18.

33. Liang XF, Yu XT, Han J, Yu HH, Chen P, Wu XF, et al. Effects of dietary protein sources on growth performance and feed intake regulation of grass carp (Ctenopharyngodon idellus). Aquaculture. 2019;510:216-24.

34. Odedeyi DO, Fagbenro O, Bello-Olusoji O, Adebayo O. Length-weight relationship and condition factor of the elephant fish, mormyrus rume (Valenciennes, 1846) in river ose, southwestern Nigeria. Animal Research International. 2007;4(1):617-20.

35. Gomez-Requeni P, Mingarro M, Calduch-Giner JA, Medale F, Martin SAM, Houlihan DF, et al. Protein growth performance, amino acid utilisation and somatotropic axis responsiveness to fish meal replacement by plant protein sources in gilthead sea bream (Sparus aurata). Aquaculture. 2004;232(1-4):493-510.

36. Correa RD, Aguilar FAA, da Cruz TMP, Sabioni RE, Cyrino JEP. Partial substitution of fishmeal with soybean protein-based diets for dourado Salminus brasiliensis. Sci Agr. 2020;77(2).

37. Novriadi R, Salze G, Abebe A, Hanson T, Davis DA. Partial or total replacement of fish meal in the diets of Florida pompano Trachinotus carolinus. Aquac Res. 2019;50(5):1527-38. 
38. Zhang Y, Chen P, Liang XF, Han J, Wu XF, Yang YH, et al. Metabolic disorder induces fatty liver in Japanese seabass, Lateolabrax japonicas fed a full plant protein diet and regulated by cAMPJNK/NF-kB-caspase signal pathway. Fish Shellfish Immun. 2019;90:223-34.

39. Novriadi R, Rhodes M, Powell M, Hanson T, Davis DA. Effects of soybean meal replacement with fermented soybean meal on growth, serum biochemistry and morphological condition of liver and distal intestine of Florida pompano Trachinotus carolinus. Aquacult Nutr. 2018;24(3):1066-75.

40. Kaushik SJ, Cravedi JP, Lalles JP, Sumpter J, Fauconneau B, Laroche M. Partial or Total Replacement of Fish-Meal by Soybean Protein on Growth, Protein-Utilization, Potential Estrogenic or Antigenic Effects, Cholesterolemia and Flesh Quality in Rainbow-Trout, Oncorhynchus-Mykiss. Aquaculture. 1995;133(3-4):257-74.

41. Robaina L, Corraze G, Aguirre P, Blanc D, Melcion JP, Kaushik S. Digestibility, postprandial ammonia excretion and selected plasma metabolites in European sea bass (Dicentrarchus labrax) fed pelleted or extruded diets with or without wheat gluten. Aquaculture. 1999;179(1-4):45-56.

42. Regost C, Arzel J, Kaushik SJ. Partial or total replacement of fish meal by corn gluten meal in diet for turbot (Psetta maxima). Aquaculture. 1999;180(1-2):99-117.

43. Yun BA, Mai KS, Zhang WB, Xu W. Effects of dietary cholesterol on growth performance, feed intake and cholesterol metabolism in juvenile turbot (Scophthalmus maximus L.) fed high plant protein diets. Aquaculture. 2011;319(1-2):105-10.

44. Yan LC, Feng L, Jiang WD, Wu P, Liu Y, Jiang J, et al. Dietary taurine supplementation to a plant protein source-based diet improved the growth and intestinal immune function of young grass carp (Ctenopharyngodon idella). Aquacult Nutr. 2019;25(4):873-96.

45. Zhou F, Song WX, Shao QJ, Peng XA, Xiao JX, Hua Y, et al. Partial Replacement of Fish Meal by Fermented Soybean Meal in Diets for Black Sea Bream, Acanthopagrus schlegelii, Juveniles. J World Aquacult Soc. 2011;42(2):184-97.

46. Liu XN, Chhipa RR, Pooya S, Wortman M, Yachyshin S, Chow LML, et al. Discrete mechanisms of mTOR and cell cycle regulation by AMPK agonists independent of AMPK. P Natl Acad Sci USA. 2014;111(4):E435-E44.

47. Jiang HW, Bian FY, Zhou HH, Wang X, Wang KD, Mai KS, et al. Nutrient sensing and metabolic changes after methionine deprivation in primary muscle cells of turbot (Scophthalmus maximus L.). J Nutr Biochem. 2017;50:74-82.

\section{Tables}

\section{Table 1}

Compositions of diets replacement with low and high level of rapeseed meal 


\begin{tabular}{|llll|}
\hline \multirow{2}{*}{ Item } & \multicolumn{2}{l}{ Experimental diets } \\
\cline { 2 - 3 } & Control & RSL & RSH \\
\hline Ingredients (\%) & & & \\
\hline Fish meal & 76 & 69.8 & 57.5 \\
\hline Rapeseed meal & - & 10 & 30 \\
\hline a - Starch & 7 & 5 & 0.9 \\
\hline Fish oil & 4 & 4 & 4 \\
\hline Vitamin premix1 & 2 & 2 & 2 \\
\hline Mineral premix2 & 2 & 2 & 2 \\
\hline Sodium carboxymethylcellulose & 1 & 1 & 1 \\
\hline Cellulose & 8.00 & 6.20 & 2.60 \\
\hline Compositions (\%) & & & \\
\hline Crude protein & 56.02 & 55.10 & 54.72 \\
\hline Crude lipid & 5.71 & 7.12 & 6.58 \\
\hline Carbohydrate & 20.73 & 20.51 & 22.75 \\
\hline Ash & 17.13 & 16.86 & 15.53 \\
\hline Moisture & 0.41 & 0.41 & 0.42 \\
\hline Gross energy (kJ kg-1) & 1400.44237 & 1400.85102 & 1401.501164 \\
\hline
\end{tabular}

${ }^{1}$ Vitamin premix (per kg of diet): vitamin A, $2000 \mathrm{IU}$; vitamin B1 (thiamin), $5 \mathrm{mg}$; vitamin B2 (riboflavin), 5 mg; vitamin B6,5 mg; vitamin B12, 0.025 mg; vitamin D3, 1200 IU; vitamin E 21 mg; vitamin K3 2.5 mg; folic acid, $1.3 \mathrm{mg}$; biotin, $0.05 \mathrm{mg}$; pantothenic acid calcium, $20 \mathrm{mg}$; inositol, $60 \mathrm{mg}$; ascorbic acid (35\%), $110 \mathrm{mg}$; niacinamide, $25 \mathrm{mg}$.

${ }^{2}$ Mineral premix (per kg of diet): MnSO4, 10 mg; MgSO4, 10 mg; KCl, 95 mg; NaCl, 165 mg; ZnSO4, 20 mg; Kl, 1 mg; CuSO4,12.5 mg; FeSO4, 105 mg; Na2SeO3, 0.1 mg; Co, 1.5 mg.

\section{Table 2}

Primers used in this experiment 


\begin{tabular}{|c|c|c|c|c|}
\hline Gene name & Sequence 5'-3' & $\operatorname{Tm}\left({ }^{\circ} \mathrm{C}\right)$ & Product size (bp) & E-values (\%) \\
\hline \multirow[t]{2}{*}{$r p / 13 a$} & CACCCTATGACAAGAGGAAGC & 59 & 100 & 102.9 \\
\hline & TGTGCCAGACGCCCAAG & & & \\
\hline \multirow[t]{2}{*}{ NPY } & GTTGAAGGAAAGCACAGACA & 55 & 191 & 103.4 \\
\hline & GCTCATAGAGGTAAAAGGGG & & & \\
\hline \multirow[t]{2}{*}{$A g R P$} & GAGCCAAGCGAAGACCAGA & 60 & 151 & 101 \\
\hline & GCAGCACGGCAAATGAGAG & & & \\
\hline \multirow[t]{2}{*}{ POMC } & GTGTCATCCTCGTTACTGC & 58 & 162 & 97.7 \\
\hline & GCGACGCTCCTATTCAAT & & & \\
\hline \multirow[t]{2}{*}{ leptinA } & CCTCTGCCAGTGGAAGTA & 58 & 188 & 95.9 \\
\hline & GTGTCAGAGATCAGGCTGT & & & \\
\hline \multirow[t]{2}{*}{ PEPCK } & CTGAGTTTGTGAAGAGAGCGG & 57 & 170 & 100.3 \\
\hline & GTCCTTTGGGTCTGTGCGT & & & \\
\hline \multirow[t]{2}{*}{ SREBP1 } & СTCССTCCTTTCTGTCGGCTC & 58 & 111 & 103.2 \\
\hline & TCATTTGCTGGCAGTCGTGG & & & \\
\hline \multirow[t]{2}{*}{ PPARa } & GGGTGTGCTCAGACAAGGCT & 58 & 146 & 105.4 \\
\hline & GTTGCGGTTCTTCTTTTGGAT & & & \\
\hline \multirow[t]{2}{*}{ FAS } & ATGGAAATCACCCCTGTAATCTT & 57 & 203 & 101.9 \\
\hline & CTTATCTGACTACGGAATGAATCG & & & \\
\hline \multirow[t]{2}{*}{$A C C 1$} & TATGCCCACTTACCCAAATGC & 58 & 129 & 102 \\
\hline & TGCCACCATACCAATCTCGTT & & & \\
\hline \multirow[t]{2}{*}{ CPT1 } & ATGGTGTATTGGCTGGAGTCT & 57.5 & 139 & 102.8 \\
\hline & CTGTGTGGTAGGTTTTCCTTGAT & & & \\
\hline \multirow[t]{2}{*}{$P C$} & GTCCCGTTCCAGATGC & 54 & 257 & 101 \\
\hline & CTGCCAGTTTCAGATAGTAGTCC & & & \\
\hline \multirow[t]{2}{*}{ G6PD } & CTGAGTTTGTGAAGAGAGCGG & 57 & 170 & 100.3 \\
\hline & GTCCTTTGGGTCTGTGCGT & & & \\
\hline$L P L$ & TTACCCCAATGGAGGCACTT & 58 & 277 & 98.8 \\
\hline
\end{tabular}


CGGACCTTGTTGATGTTGTAG

\begin{tabular}{lllll}
$H L$ & CAACCCTGAAGACAAATCTAATA & 57.5 & 180 & 96.3 \\
\hline CAATCAAATGAGCCTTTCTAACT & & & 104 \\
\hline & ACAAACGCCTGGGAATGGT & 60 & 125 & \\
& TGTGGTCCGCCCTGAAGAA & & &
\end{tabular}

\section{Table 3}

Growth performance and feed utilization of Chinese perch fed with different levels of rapeseed meal diet.

\begin{tabular}{|llll|}
\hline & Control & RSL & RSH \\
\hline Initial Weight (g) & $48.06 \pm 2.03$ & $45.25 \pm 2.28$ & $46.53 \pm 2.47$ \\
\hline Final Weight (g) & $70.81 \pm 4.24$ & $61.99 \pm 6.19$ & $54.48 \pm 3.55$ \\
WG (g) & $22.60 \pm 2.82^{\mathrm{a}}$ & $9.89 \pm 0.27^{\mathrm{b}}$ & $6.39 \pm 1.99^{\mathrm{b}}$ \\
\hline SGR & $0.92 \pm 0.11^{\mathrm{a}}$ & $0.44 \pm 0.02^{\mathrm{b}}$ & $0.30 \pm 0.10^{\mathrm{b}}$ \\
\hline FCR & $2.67 \pm 0.24^{\mathrm{a}}$ & $4.61 \pm 0.57^{\mathrm{a}}$ & $10.64 \pm 2.58^{\mathrm{b}}$ \\
\hline
\end{tabular}

Data are presented as mean \pm S.E.M of three replicates $(n=6)$. The same row with different letters indicates significant differences between groups based on one-way analysis of variance (ANOVA) followed by the post hoc test $(P<0.05)$.

\section{Table 4}

Fatness of Chinese perch fed with different levels of rapeseed meal diet.

\begin{tabular}{|llll|}
\hline & Control & RSL & RSH \\
\hline CF & $0.0149 \pm 0.0004^{\mathrm{a}}$ & $0.0141 \pm 0.0003^{\mathrm{ab}}$ & $0.0135 \pm 0.0002^{\mathrm{b}}$ \\
$\mathrm{HSI}$ & $1.3751 \pm 0.2087$ & $0.9568 \pm 0.1250$ & $0.9452 \pm 0.1099$ \\
$\mathrm{VSI}$ & $10.4419 \pm 1.0337^{\mathrm{a}}$ & $6.5794 \pm 0.9852^{\mathrm{b}}$ & $7.3789 \pm 0.6469^{\mathrm{b}}$ \\
\hline BFR & $0.4251 \pm 0.0384^{\mathrm{a}}$ & $0.0968 \pm 0.0364^{\mathrm{b}}$ & $0.1972 \pm 0.0442^{\mathrm{b}}$ \\
\hline MFI & $2.4006 \pm 0.1667^{\mathrm{a}}$ & $1.6918 \pm 0.2089^{\mathrm{b}}$ & $1.4751 \pm 0.2320^{\mathrm{b}}$ \\
\hline
\end{tabular}


Data are presented as mean \pm S.E.M of three replicates $(n=6)$. The same row with different letters indicates significant differences between groups based on one-way analysis of variance (ANOVA) followed by the post hoc test $(P<0.05)$.

\section{Table 5}

Whole body composition of Chinese perch fed with different levels of rapeseed meal diet.

\begin{tabular}{|lllll|}
\hline & Moisture & Crude Protein & Crude Lipid & Crude Ash \\
\hline Control & $75.34 \pm 0.32^{\mathrm{a}}$ & $16.20 \pm 0.10$ & $3.14 \pm 0.36^{\mathrm{a}}$ & $4.89 \pm 0.23^{\mathrm{a}}$ \\
\hline RSL & $78.14 \pm 0.30^{\mathrm{b}}$ & $15.52 \pm 0.32$ & $0.94 \pm 0.52^{\mathrm{b}}$ & $6.36 \pm 0.44^{\mathrm{b}}$ \\
\hline RSH & $77.11 \pm 0.48^{\mathrm{b}}$ & $16.24 \pm 0.25$ & $1.72 \pm 0.61^{\mathrm{b}}$ & $5.23 \pm 0.24^{\mathrm{a}}$ \\
\hline
\end{tabular}

Data are presented as mean \pm S.E.M of three replicates $(n=6)$. The same row with different letters indicates significant differences between groups based on one-way analysis of variance (ANOVA) followed by the post hoc test $(P<0.05)$.

\section{Table 6}

Tissue composition of Chinese perch fed with different levels of rapeseed meal diet.

\begin{tabular}{|llll|}
\hline & Moisture & Crude Protein & Crude Lipid \\
\hline Liver & & & \\
\hline Control & $73.89 \pm 0.79^{\mathrm{a}}$ & $13.78 \pm 1.25$ & $2.51 \pm 0.45$ \\
\hline RSL & $77.69 \pm 0.71^{\mathrm{b}}$ & $16.22 \pm 0.84$ & $2.26 \pm 0.29$ \\
\hline RSH & $78.31 \pm 1.10^{\mathrm{b}}$ & $15.79 \pm 0.75$ & $2.15 \pm 0.35$ \\
\hline Muscle & & & \\
\hline Control & $79.52 \pm 0.25$ & $19.97 \pm 0.60$ & $0.99 \pm 0.20$ \\
\hline RSL & $79.25 \pm 0.53$ & $19.48 \pm 0.53$ & $1.60 \pm 0.38$ \\
\hline RSH & $79.39 \pm 0.20$ & $20.08 \pm 0.13$ & $1.49 \pm 0.14$ \\
\hline
\end{tabular}

Data are presented as mean \pm S.E.M of three replicates $(n=6)$. The same row with different letters indicates significant differences between groups based on one-way analysis of variance (ANOVA) followed by the post hoc test $(P<0.05)$. 


\section{Table 7}

Serum biochemistry parameters of Chinese perch fed with different levels of rapeseed meal diet.

\begin{tabular}{|lllllll|}
\hline & Total Protein & GLU & Total Cholesterol & TG & HDL-C & LDL-C \\
\hline Control & $32.47 \pm 0.68^{\mathrm{a}}$ & $8.82 \pm 0.41^{\mathrm{a}}$ & $4.65 \pm 0.35^{\mathrm{a}}$ & $1.87 \pm 0.33$ & $0.87 \pm 0.08$ & $0.77 \pm 0.08^{\mathrm{a}}$ \\
\hline RSL & $26.65 \pm 1.10^{\mathrm{b}}$ & $8.35 \pm 1.27^{\mathrm{ab}}$ & $3.53 \pm 0.12^{\mathrm{ab}}$ & $1.30 \pm 0.16$ & $0.75 \pm 0.02$ & $0.24 \pm 0.03^{\mathrm{b}}$ \\
\hline RSH & $25.16 \pm 1.01^{\mathrm{b}}$ & $7.39 \pm 1.07^{\mathrm{b}}$ & $3.97 \pm 0.23^{\mathrm{b}}$ & $1.15 \pm 0.17$ & $0.84 \pm 0.05$ & $0.20 \pm 0.02^{\mathrm{b}}$ \\
\hline
\end{tabular}

Data are presented as mean \pm S.E.M of three replicates $(n=6)$. The same row with different letters indicates significant differences between groups based on one-way analysis of variance (ANOVA) followed by the post hoc test $(P<0.05)$.

Figures

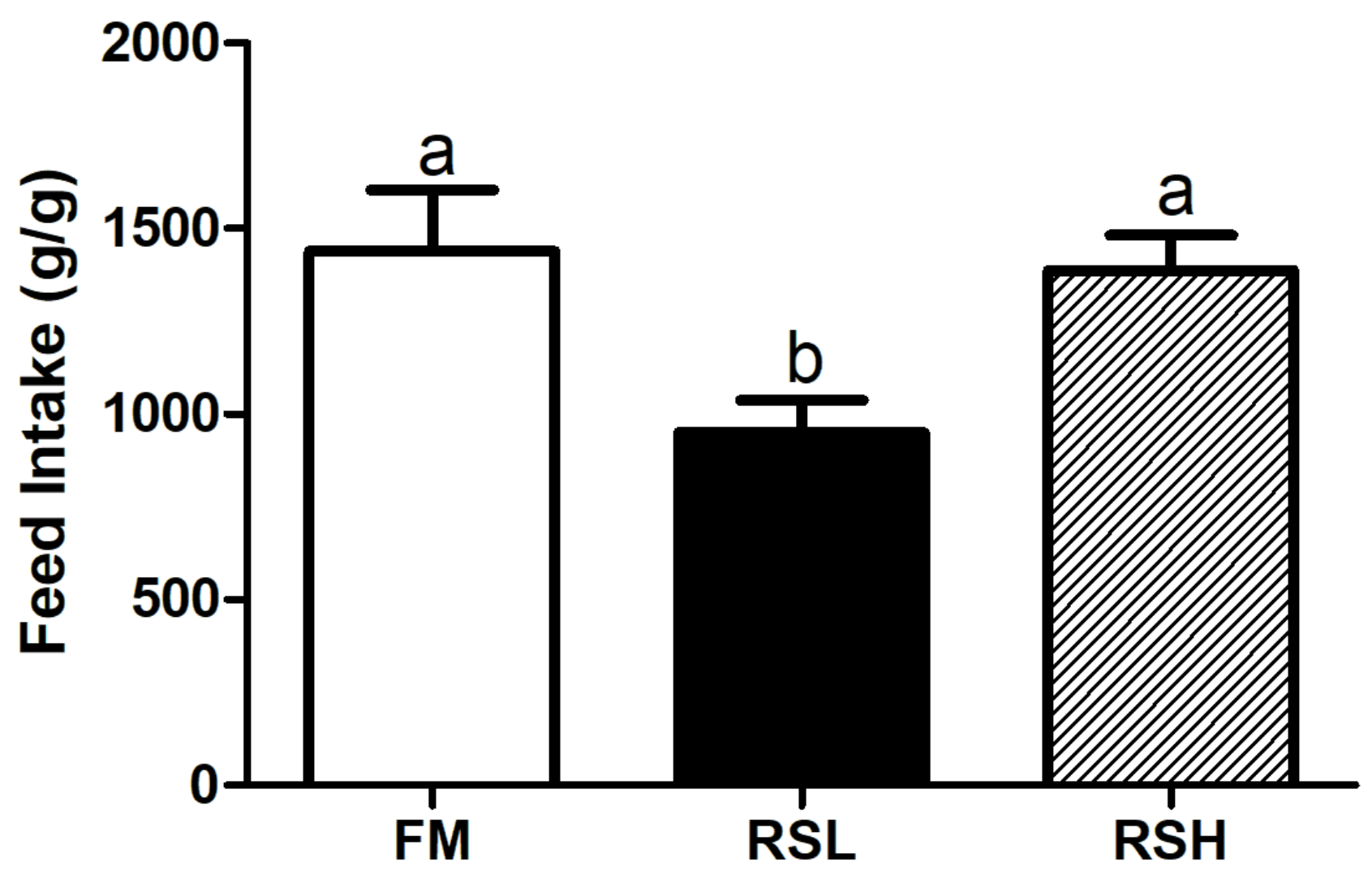

Figure 1 
Feed intake of Chinese perch fed with different levels of rapeseed meal diet. Data are presented as mean \pm S.E.M of three replicates $(n=6)$. The same row with different letters indicates significant differences between groups based on one-way analysis of variance (ANOVA) followed by the post hoc test $(P<0.05)$.

a

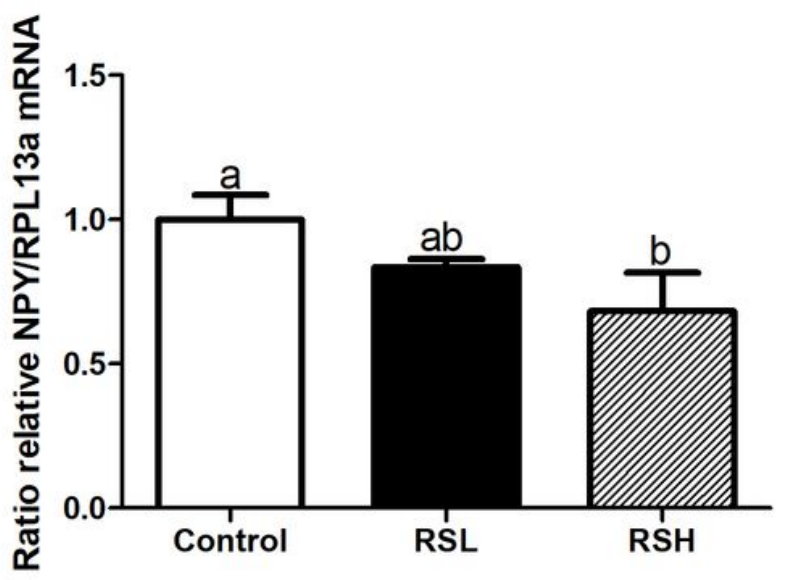

C

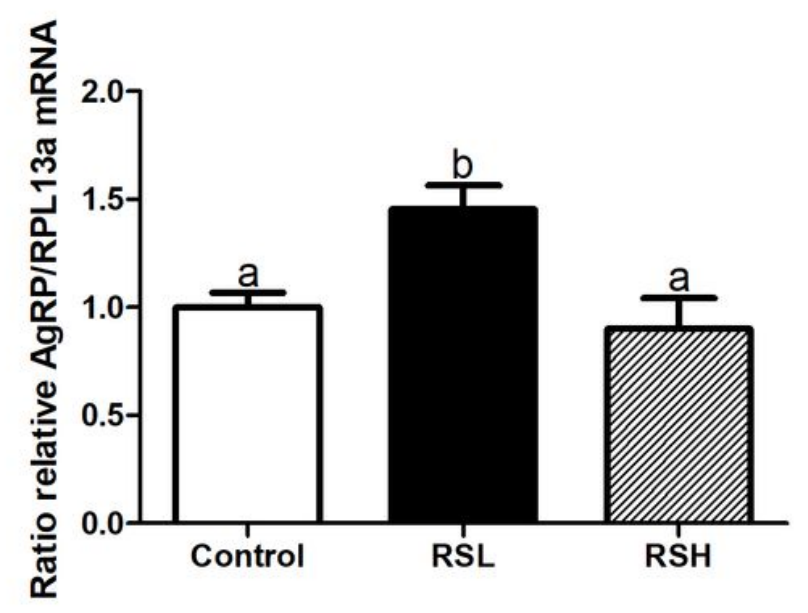

b

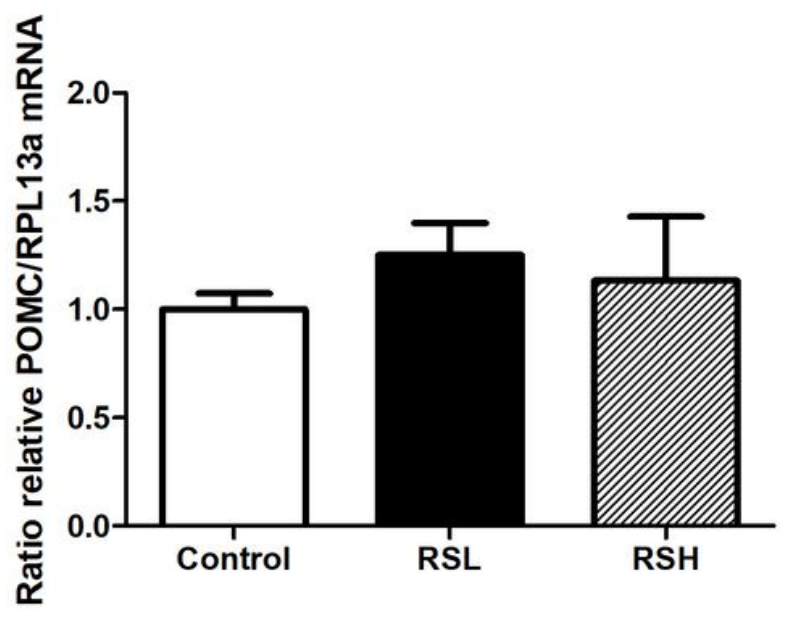

d

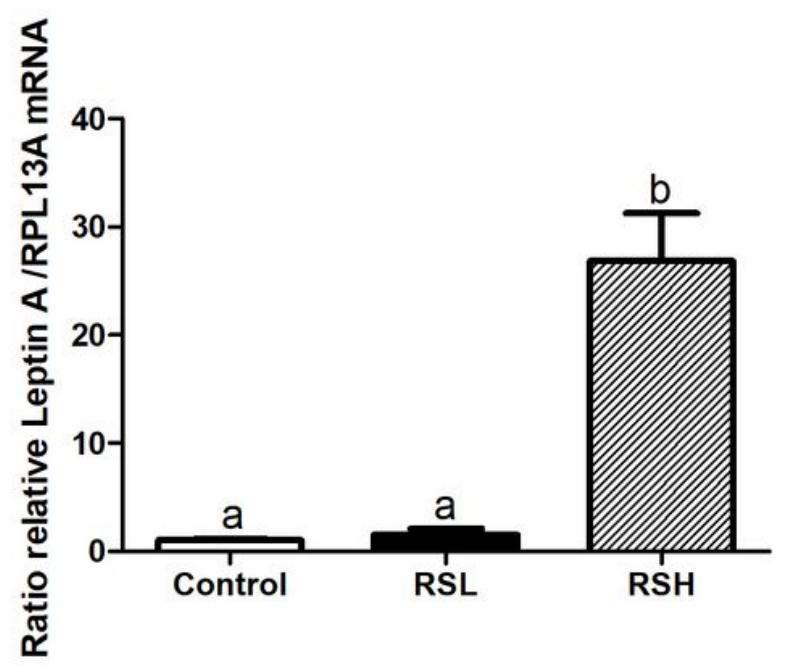

Figure 2

Expression of appetite relative genes of Chinese perch fed with different levels of rapeseed meal diet. Data are presented as mean \pm S.E.M of three replicates $(n=6)$. The same row with different letters indicates significant differences between groups based on one-way analysis of variance (ANOVA) followed by the post hoc test $(P<0.05)$. 
A

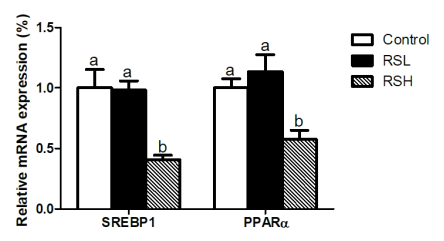

D

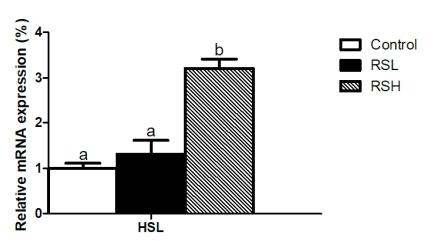

B

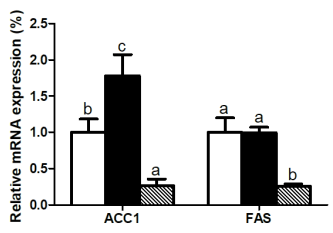

E

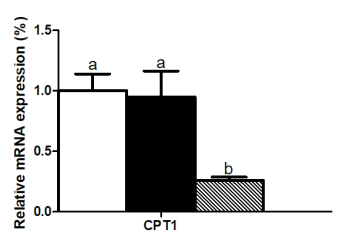

C

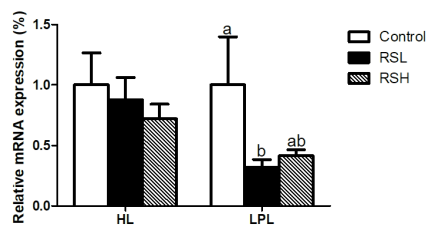

$\mathbf{F}$

G
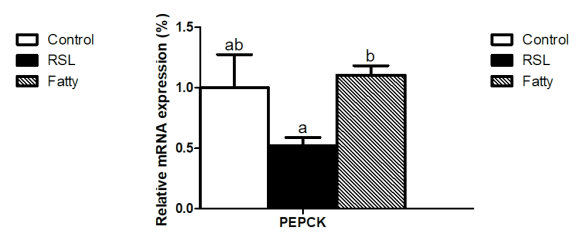

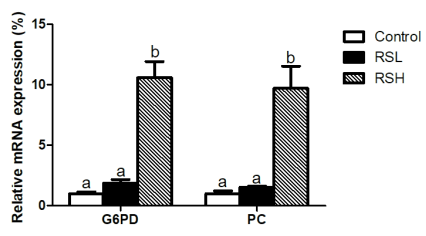

Figure 3

Expression of lipid and glucose metabolism relative genes in liver tissue of Chinese perch fed with different levels of rapeseed meal diet. Data are presented as mean \pm S.E.M of three replicates $(n=6)$. The same row with different letters indicates significant differences between groups based on one-way analysis of variance (ANOVA) followed by the post hoc test $(P<0.05)$.

A

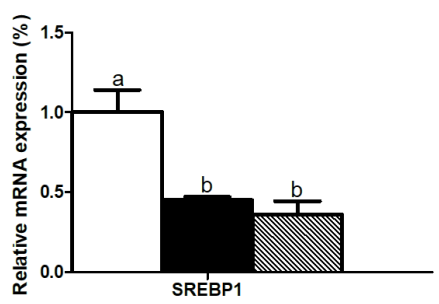

D
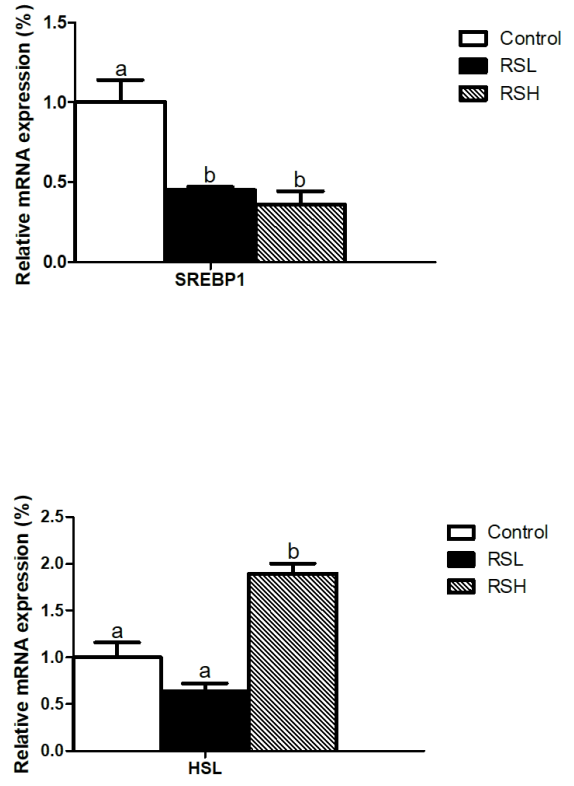

B

E

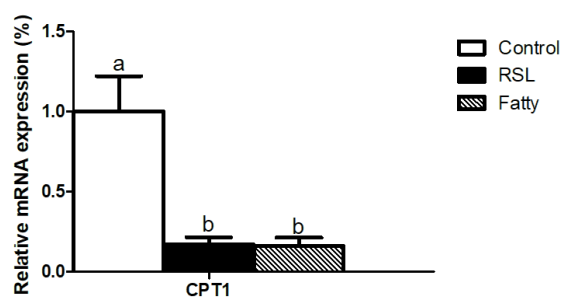

C

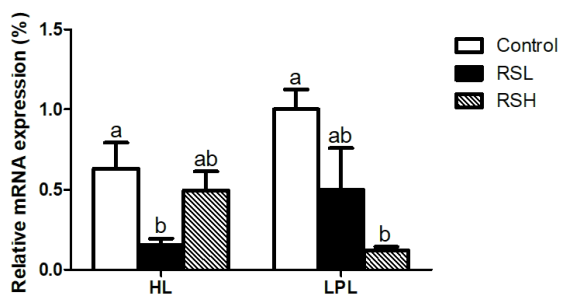

$\mathbf{F}$

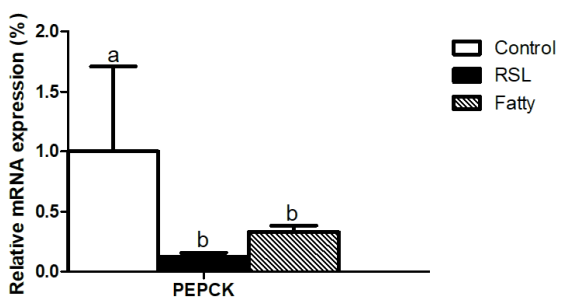

Figure 4

Expression of lipid and glucose metabolism relative genes in visceral adipose tissue of Chinese perch fed with different levels of rapeseed meal diet. Data are presented as mean \pm S.E.M of three replicates $(n=6)$. The same row with different letters indicates significant differences between groups based on one-way analysis of variance (ANOVA) followed by the post hoc test $(P<0.05)$. 


\section{Control RSL RSH}

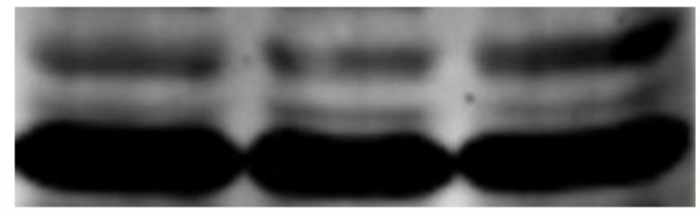

p-AMPK

$\beta$-tublin

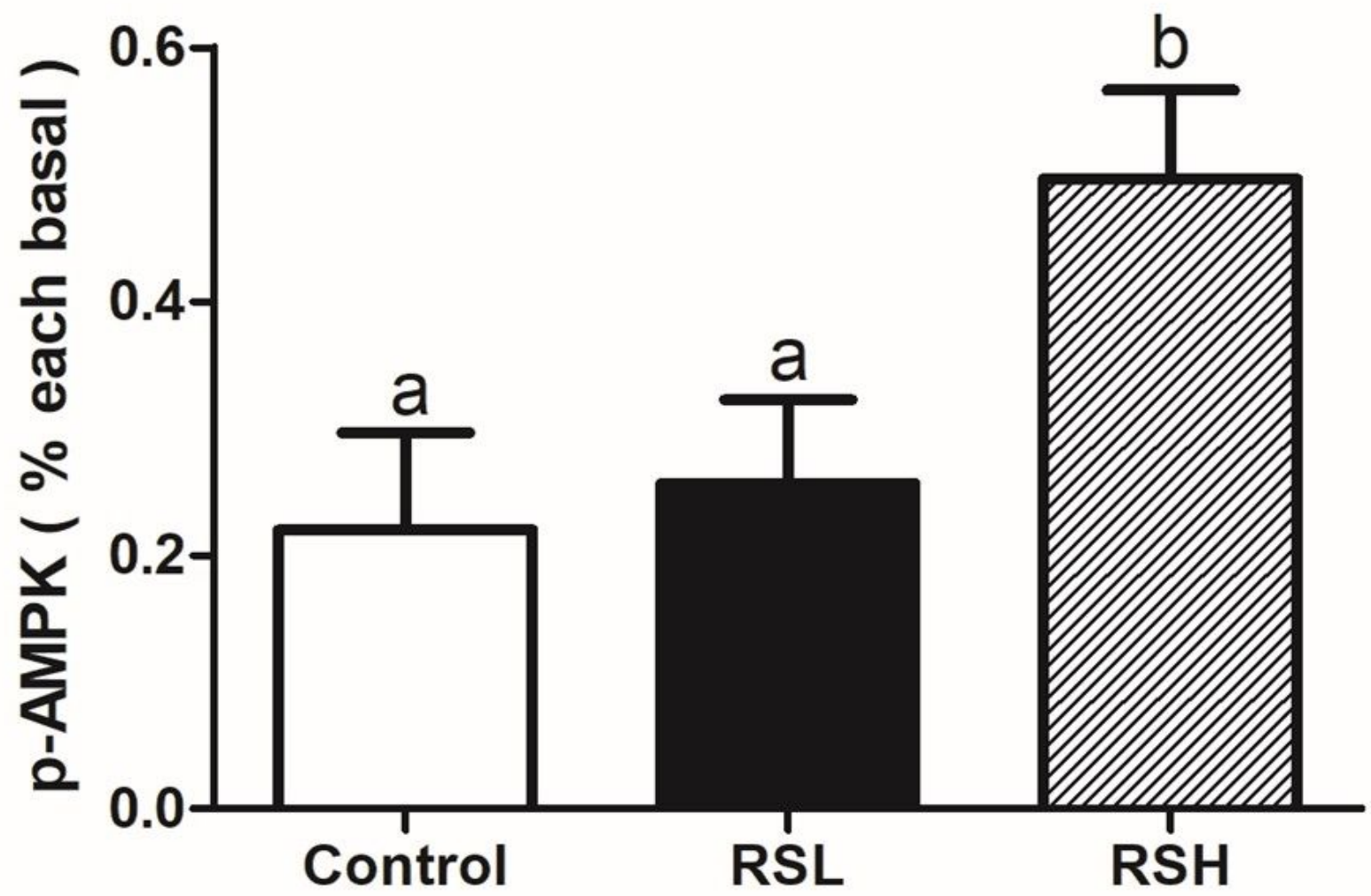

Figure 5

Phosphorylation of AMPK of Chinese perch fed with different levels of rapeseed meal diet. Data are presented as mean \pm S.E.M of three replicates $(n=6)$. The same row with different letters indicates significant differences between groups based on one-way analysis of variance (ANOVA) followed by the post hoc test $(P<0.05)$. 


\section{Control RSL RSH}

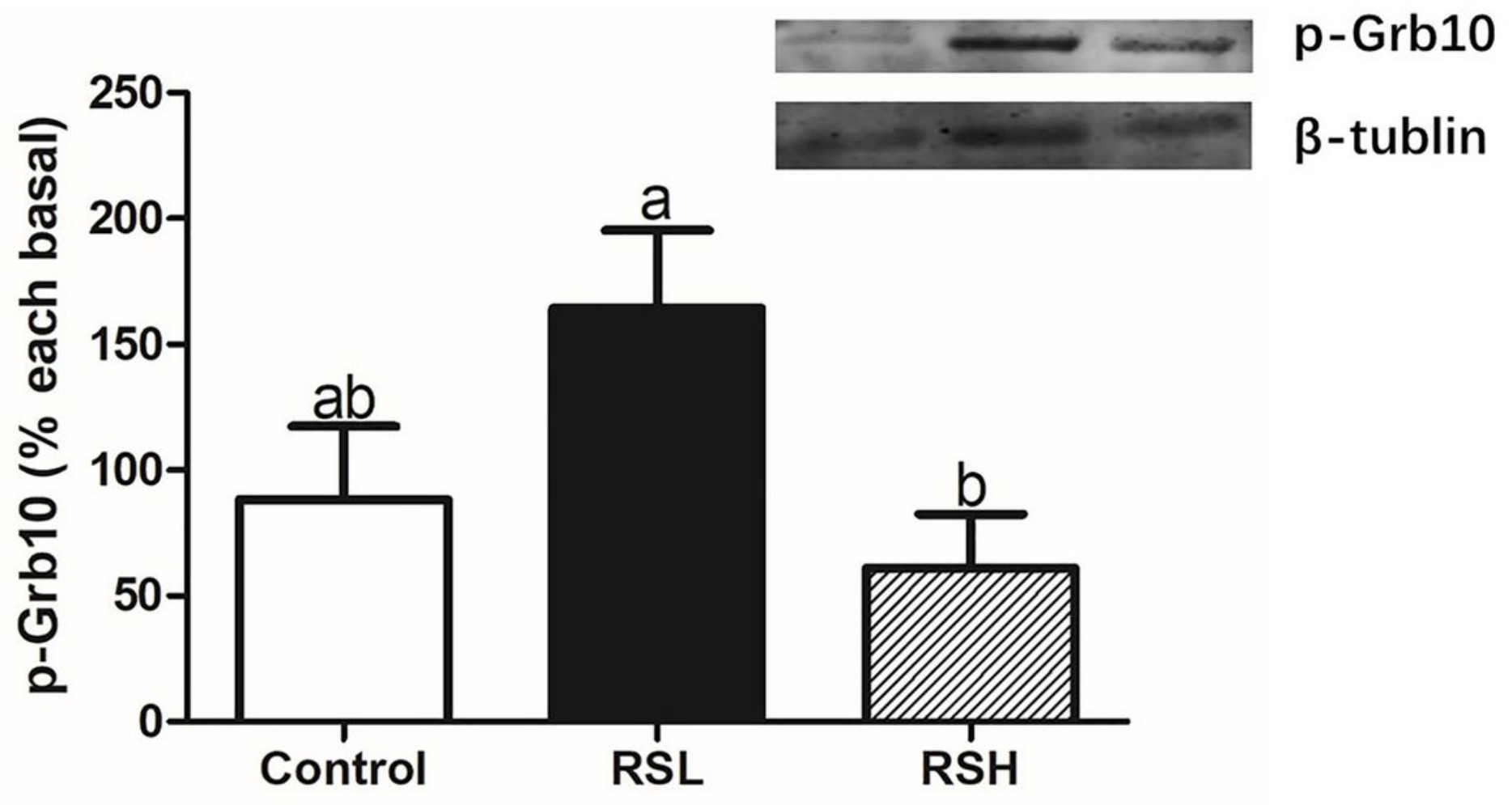

Figure 6

Phosphorylation of Grb10 of Chinese perch fed with different levels of rapeseed meal diet. Data are presented as mean \pm S.E.M of three replicates $(n=6)$. The same row with different letters indicates significant differences between groups based on one-way analysis of variance (ANOVA) followed by the post hoc test $(P<0.05)$. 


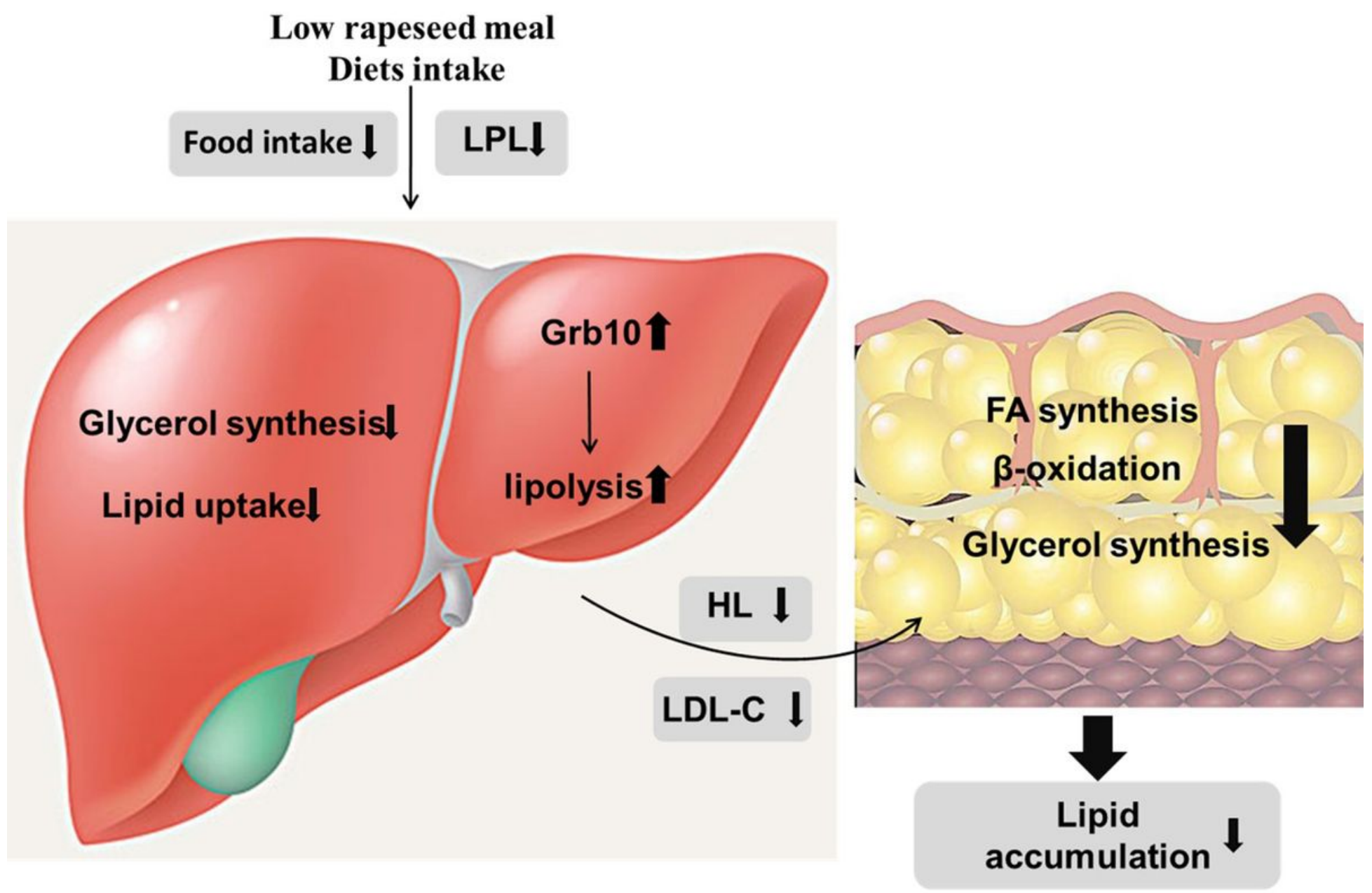

Figure 7

Metabolic process of Chinese perch fed with RSL diet. Fish fed with low level replacement of rapeseed meal diet decreased in feed intake and phosphorylated Grb10, which was improved lipolysis, inhibited glycerol synthesis and lipid uptake. These metabolic activities decreased transportation of lipid from liver to visceral adipose tissue, then FA synthesis, $\beta$-oxidation and glycerol synthesis were inhibited. Finally, lipid accumulation of Chinese perch were decreased. 


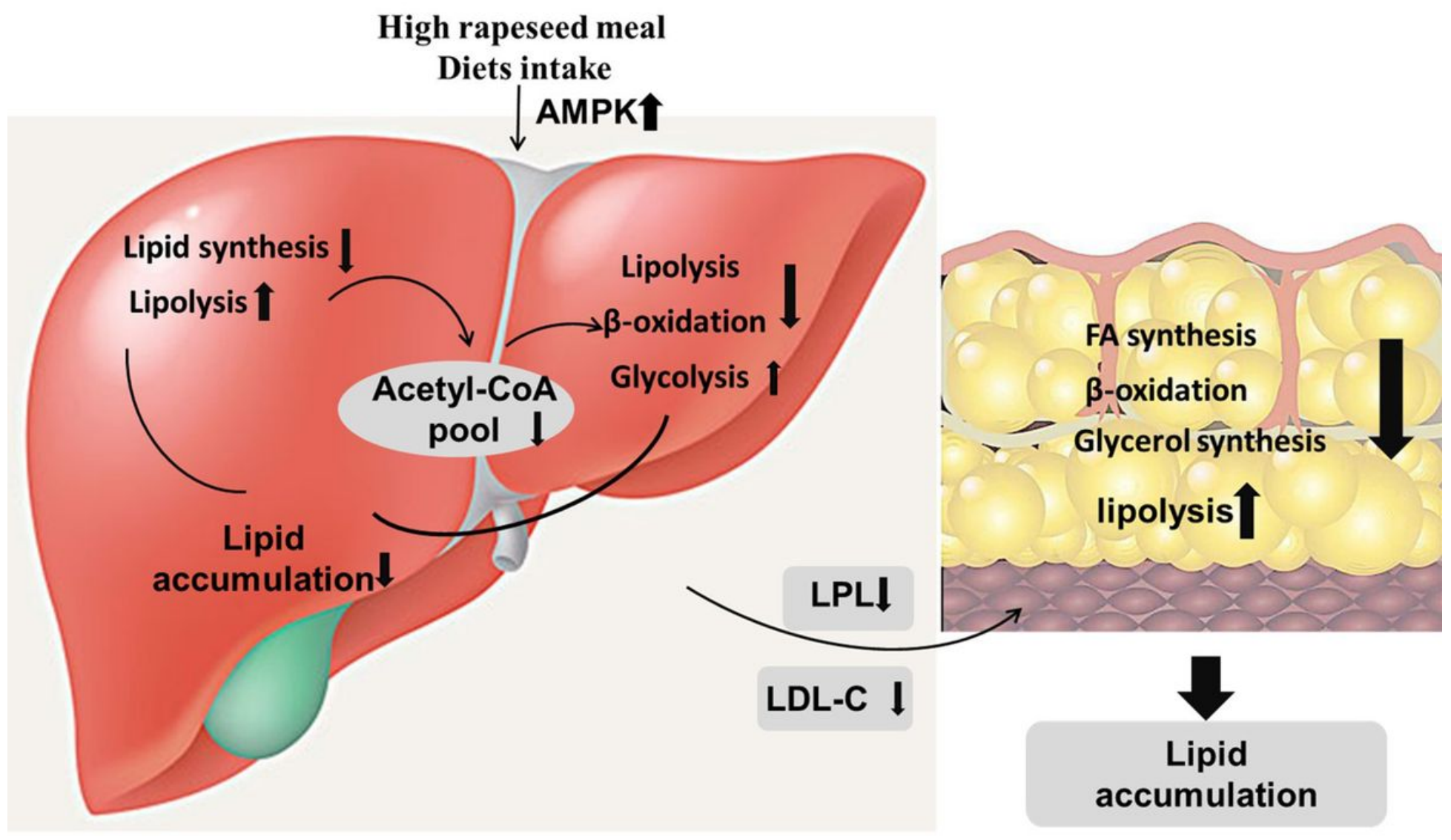

Figure 8

Metabolic process of Chinese perch fed with RSH diet. Fish fed with RSH diets phosphorylated AMPK, inhibited FA synthesis, while improved lipolysis, and these metabolic processes reduced Acetyl-CoA pool. In turn, \-oxidation was inhibited, while glycolysis was improved, and then lipid accumulation was decreased. In visceral adipose tissue, lipid uptake were inhibited, inhibiting FA synthesis, $\beta$-oxidation, glycerol synthesis, improving lipolysis. 